\title{
The QUALITY AND RESEARCH TREND ON SUbJECT AREA Automation \& Manufacturing Published by DAAAM
}

\author{
AChSAn, H. T.; Suhartanto, H. S. \& Wibowo, W. C.
}

Abstract: DAAAM is a prestigious conference organizer since 1990. Unfortunately, Scimago Journal \& Country Rank (SJR) has scored and ranked lower on Annals of $D A A A M$ and Proceedings of the International DAAAM Symposiums. This paper aims to clarify the situation and also to seek the research trend on the subject areas of Automation \& Manufacturing in scientific papers published by DAAAM. The methods used in this research was data mining and bibliometric applied to all 5,939 papers, from 2005 to 2016, in Annals of DAAAM and Proceedings of the International DAAAM Symposiums indexed by Scopus. The results of this research reveal that there was lack of data in Scopus, inaccurate data in SJR, and higher quality of DAAAM publications.

Key words: Bibliometric, DAAAM, Expertise, Performance, Conference, Research Trend
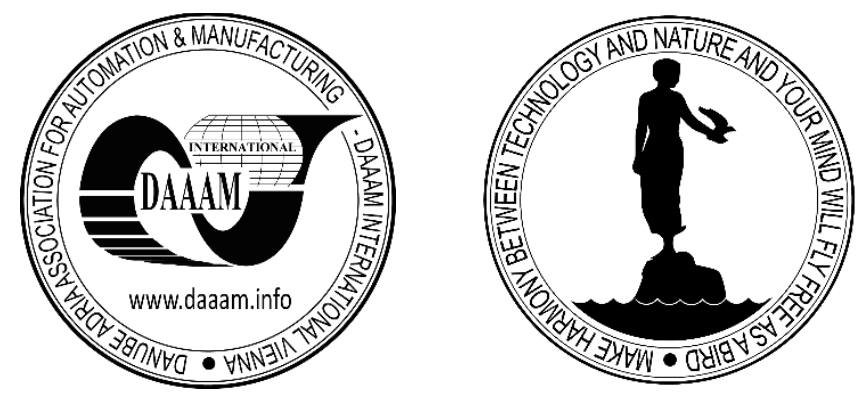

Authors' data: Achsan, H[arry] T[ Yani]; Suhartanto, H[eru] S[eok] \& Wibowo, W[ahyu] C[atur], Paramadina University, J1. Gatot Subroto Kav. 97, 12970 Jakarta Indonesia, harry.achsan@paramadina.ac.id

This Publication has to be referred as: Achsan, H[arry] T[ Yani]; Suhartanto, H[eru] S[eok] \& Wibowo, W[ahyu] C[atur] (2017). The Quality and Research Trend on Subject Area Automation \& Manufacturing Published by DAAAM, Chapter 22 in DAAAM International Scientific Book 2017, pp.291-304, B. Katalinic (Ed.), Published by DAAAM International, ISBN 978-3-902734-12-9, ISSN 1726-9687, Vienna, Austria

DOI: $10.2507 /$ daaam.scibook.2017.22 
Achsan, H. T.; Suhartanto, H. S. \& Wibowo, W. C.: The Quality and Research Tren...

\section{Introduction}

Keywords of "conference on manufacturing and automation" was searched using Google on October 25th, 2017, generating a list of 61.5 million of web pages. From the list, only 4 of the first top 10 conferences ranked by Google were seen on Scopus. Among them, only 1 conference proceeding indexed by Scopus continuously every year. Danube Adria Association for Automation \& Manufacturing (DAAAM) conference was not on the top 10. It was ranked 77th by Google. It can be inferred that it was a satisfying result since DAAAM web site was ranked 77th from 61.5 million. Moreover, DAAAM is one of the prestigious conference organizer because the conferences conducted annually/continuously since 1990 [1], supported by more than 10.000 scientists and experts from over fifty countries all over the world [1], and indexed by Scopus.

In contrary, Scimago Journal \& Country Rank (SJR), an institution with mission to score and rank of journals, book series and conferences across the world by using Bibliometrics, has announced that "Annals of DAAAM and Proceedings of the International DAAAM Symposium" was in poor condition. Fig. 1 shows that citations per document is very low and has no international collaboration. SJR also ranked "Annals of DAAAM and Proceedings of the International DAAAM Symposium" at position 20th out of 70 scientific publications in Italy [2]. There is always room for improvement. To verify the result issued by SJR, so we did an exploration of DAAAM publications indexed by Scopus. The results of our preliminary research was contrast to SJR metrics, and it raised a research question: how exactly is DAAAM publications quality?

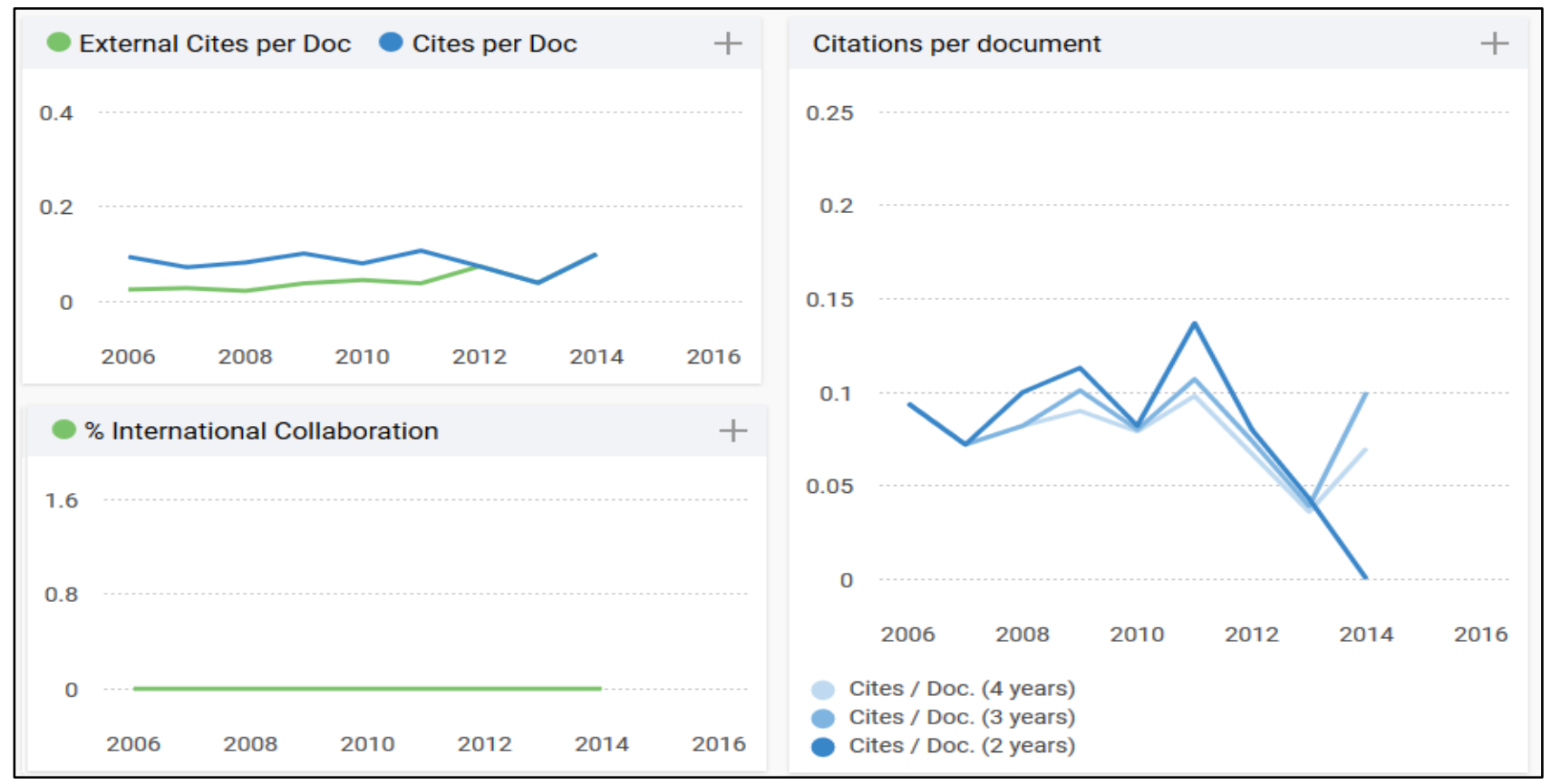

Fig. 1. Bibliometric of Annals of DAAAM and Proceedings of the International DAAAM Symposium by Scimago Journal \& Country Rank. [3] 
A clarification should be made because SJR is used as a reference to: indicate quality of scientific publications [4, 5], evaluate research and scientific activities [6, 7], identify and evaluate characteristic of a publication [8], map information literacy literature [9], and country productivity in research $[10,11]$. Data used by SJR to rank DAAAM publications has to be collected and analysed. These data should be compared to actual publications listed on official DAAAM web site. Data from Scopus web site can also be used to compute number of citations per document and then to be compared to the same data computed by SJR.

This research was not intended to clarify SJR rank only because the preliminary research also spawns further research questions: what is research trend on Automation \& Manufacturing based on DAAAM publications? And what is the characteristic of DAAAM publications and its authors? To answer the research trend, we have to analyse controlled vocabularies applied to each paper and also consider the keywords supplied by the authors. Characteristic of DAAAM publications and its authors can be pursued by applying bibliometric on bibliography available on DAAAM and Scopus web site.

\section{Related works}

Many researches were conducted on analysing SJR and Scopus data. The methods were varying, some used Impact Factor (IF) [12, 13, 14], Eigenfactor Score (ES) [12, 13], h-index [13], h5-index [15], g-index [13], source normalized impact per paper [13], article influence score [13], number of citation [9], and the scientometric [12]. Those methods are parts of bibliometric and scientometric. None of the metrics are specific to engineering, but proven useful in natural and social science disciplines [13].

The results of those researches are: significant association between SJR and scientometric features in obstetrics and gynecology journals [12], SJR may be an appropriate index for assessing journal quality [12], papers on a subject area tend to get citations much more than other subject are [14], and criticisms of citation metrics [13], etc. Although citations metric has been criticized, it is still used as publication assessment method. SJR also still use citation metrics, and SJR still be used for assessing publication quality.

Since people still use SJR to assess the quality of publication, so sometimes the quality of publication should be computed by ourselves to check the information published by SJR. Bibliometric and scientometric can be used as the methods as stated above. These methods need bibliography or metadata of publications. It can be downloaded from Google Scholar (GS), Web of Science (WoS), Directory of Open Access Journals (DOAJ), SJR, Scopus, etc. Except GS, all those web sites are structured. GS is structured web site, but it only gives links to the publications, and the related sites very vary in structure and sometimes unstructured. Since this research only used metadata mainly from SJR and Scopus, method for data mining used was focused web crawling [16]. 
Achsan, H. T.; Suhartanto, H. S. \& Wibowo, W. C.: The Quality and Research Tren...

\section{Data and Methods}

\subsection{Data source}

Our research focused to analyse DAAAM conference papers published in period from 2005 to 2016. Full text of DAAAM conference papers were downloaded from its official web site (http://daaam.info/). Bibliography of DAAAM conference papers were downloaded from Scopus using advanced query term "CONF(DAAAM)". The result was a list of 5,939 documents published in 3 different serials: Annals of DAAAM and Proceedings of the International DAAAM Symposium (89\%), Procedia Engineering (7\%), and Energy Procedia (4\%), see Fig. 2.

\begin{tabular}{|c|c|c|c|}
\hline \multirow[t]{4}{*}{ Publication by Source Title } & City & $\begin{array}{c}\text { Number of } \\
\text { Author }\end{array}$ & $\begin{array}{l}\text { Assigned } \\
\text { Country }\end{array}$ \\
\hline & [no data] & 1,750 & - \\
\hline & Brasov & 6 & Romania \\
\hline & Bucarest-Magurele & 1 & Romania \\
\hline \begin{tabular}{|c|c|} 
Procedia Engineering & Energy Procedia \\
$7 \%$ & $4 \%$ \\
\end{tabular} & Bucharest & 13 & Romania \\
\hline \multirow{6}{*}{$\begin{array}{l}\text { Annals of DAAAM and/or Proceedings of } \\
\text { the International DAAAM Symposium } \\
\qquad 89 \%\end{array}$} & Bucuresti & 365 & Romania \\
\hline & Cluj-Napoca & 120 & Romania \\
\hline & Iasi & 2 & Romania \\
\hline & Magurele & 1 & Romania \\
\hline & Ploiesti & 2 & Romania \\
\hline & Targoviste & 1 & Romania \\
\hline & Targu Mures & 5 & Romania \\
\hline & Timisoara & 6 & Romania \\
\hline & & 2,272 & \\
\hline Fig. 2. Serials source title & \multicolumn{3}{|c|}{$\begin{array}{l}\text { Tab. 1. Assign country name based on } \\
\text { city name. }\end{array}$} \\
\hline
\end{tabular}

\subsection{Data mining}

Metadata or bibliography of all conference papers which were used in this research were available online as discussed in the previous section. Since the data/metadata only resided in 2 web sites, we used focused web crawler [16] to collect the data. The metadata downloaded from Scopus consisted of: Authors, Title, Year, Source title, Volume, Issue, Art. No., Page start, Page end, Page count, Cited by, DOI, Link, Affiliations, Authors with affiliations, Abstract, Author Keywords, Index Keywords, Molecular Sequence Numbers, Chemicals/CAS, Tradenames, Manufacturers, Funding Details, Funding Text, References, Correspondence Address, Editors, Sponsors, Publisher, Conference name, Conference date, Conference location, Conference code, ISSN, ISBN, CODEN, PubMed ID, Language of Original Document, Abbreviated Source Title, Document Type, Source, and EID (unique code for each document). 
Metadata of DAAAM publications downloaded from Scopus web site lacked affiliation; $81.8 \%$ of its authors had no affiliation. This finding became another obstacle in our research because computing collaboration level need affiliation name and computing percentage of International Collaboration need country of origin of the authors. To overcome the problem, we crawled metadata of all the authors. Unfortunately, 1,750 authors still had no affiliation and 522 had affiliation but without country name. Fortunately, those authors with no country name in the affiliation data had city name thus we assigned the country of the author affiliation based on the city name.

\subsection{Data cleansing}

Data cleansing is the process of removing noise on the data. Noise of data can be found in any form like incomplete data, duplicate data, and invalid data. In this research we found duplicate data downloaded from Scopus. For example a paper titled "Indonesia Coal Trade System: A knowledge-based application software" in 25th DAAAM International proceeding was published twice, one in Energy Procedia [17] and the other in Procedia Engineering [18]. We explored all the records we have got and found that all scientific papers in 25th DAAAM International proceeding that was published in Energy Procedia also published in Procedia Engineering, so we removed all the records with source title Energy procedia. It accounted to about $4 \%$ of total records, see Fig. 2.

There were 18 conferences/symposiums (12 International DAAAM Symposiums and 6 International DAAAM Baltic Conferences) held by DAAAM in the period 20052016, but there was no DAAAM publication indexed by Scopus in the year 2013. An investigation has been made to the data, the consequence was we had to change all of the DAAAM publications that were indexed by Scopus in the year 2014, because all of 2013 24th DAAAM International Symposium papers were index by Scopus in the year 2014. We also changed some of the DAAAM publications that were indexed by Scopus in the year 2015, because all of 2014 25th DAAAM International Symposium papers were index by Scopus in the year 2015. The correction result can be seen in Fig. 5 .

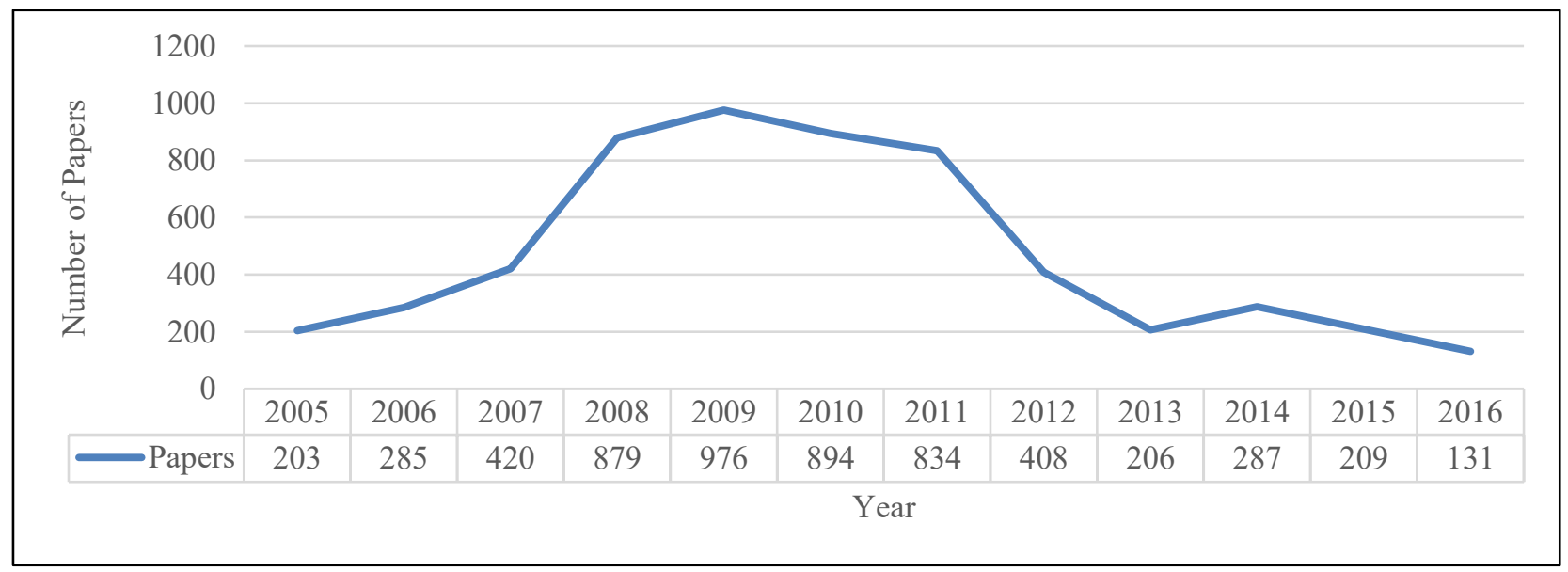

Fig. 3. DAAAM Symposium papers by year. 
Achsan, H. T.; Suhartanto, H. S. \& Wibowo, W. C.: The Quality and Research Tren...

\subsection{Bibliometric}

A review about representation level of cultural institutions in Croatia within online media indicate an inadequate representation of institutions in media [19]. To prevent the situation, higher educations and research institutions have to spread their research outcomes in reputable journals, book series and/or conference proceedings. Looking for good publishers is not challenging anymore; just search it by using reliable online bibliometric like Journal Citation Reports (JCR) and SJR. JCR and SJR use bibliometric method to rank publishers. Bibliometric is used to compute: H-Index, Number of Citations per Document, National Collaboration, International Collaboration, etc.

\subsection{H-Index}

H-Index is abbreviation of Hirsch-Index, a number to estimate of the importance, significance, and broad impact of a scientist's cumulative research contributions [20]. A publisher/author has $\mathrm{h}$-Index $\mathrm{h}$ if $\mathrm{h}$ number of papers has been published/authored by the publisher/author and each of which has been cited by other publication at least $\mathrm{h}$ times. H-Index is better indicator of journal than total citation count, citations per paper, and total paper count [21], and higher h-Index of journal editors is needed as a gatekeeper to nurture journal reputation [22].

\subsection{Citations per document}

Even though h-Index is better than citations per paper [21], we will use it to evaluate the impact factor of publications published by DAAAM. Computing citations per document will be implemented to publications prior to 2014 to make it comparable to SJR.

\subsection{Collaboration}

Collaboration level or percentage of collaboration is percentage of papers authored by more than one researcher from different affiliations. International collaboration as displayed in SJR, see Fig. 1. Bibliometric of Annals of DAAAM and Proceedings of the International DAAAM Symposium by Scimago Journal \& Country Rank. [3] Fig. 1 , is percentage of papers authored by more than one researcher from different countries.

\subsection{Research trend}

Research trend in serial publications can be predicted by analysing controlled keywords and authors keywords [23]. Controlled keywords are controlled vocabularies that applied to scientific papers. These controlled keywords also used as indices in the database to make query or searching on papers more accurate. No one allowed to add controlled vocabularies except accepted by the team who maintaining it. 


\section{Results}

\subsection{Authors characteristics}

In the period of 2005-2016, there were 6,975 authors joined the conferences/symposiums conducted by DAAAM. The portion of new comers (52\%) was about the same as repeated authors (48\%), see Fig. 4. It portrays a great process of transfer of knowledge since senior authors who are more knowledgeable shared their experience to young researchers.

It is also shows that authors reckon on the DAAAM proceedings to publish their future works. Fig. 5 shows that only $25 \%$ of authors has no h-index, meaning that half of young authors has h-index at least 1 , and three fourth of the authors has h-index at least one. It means that papers written by the authors are good in quality, because other researchers cited their papers.

Thus, the quality of DAAAM proceedings is also good. The discipline of the authors dispersed in 31 subject areas, see Table 2. The first 3 rows show that $89 \%$ engineers also knowledgeable of subject area Computer Science and 36\% knowledgeable of subject area Materials Science.

Based on geography, authors of DAAAM proceedings were from 70 different countries. Statistically, 94.1\% of authors were from Europe (Eastern Europe 68.7\%, Western Europe 14.3\%, Baltics 6.6\%, and The Commonwealth of Independent States $4.5 \%), 4.1 \%$ from Asia-Oceania, and the rest (1.8\%) were from America and Africa. Most authors in 2008-2010 were from Romania, see Table 3, the table only shows top ten countries.

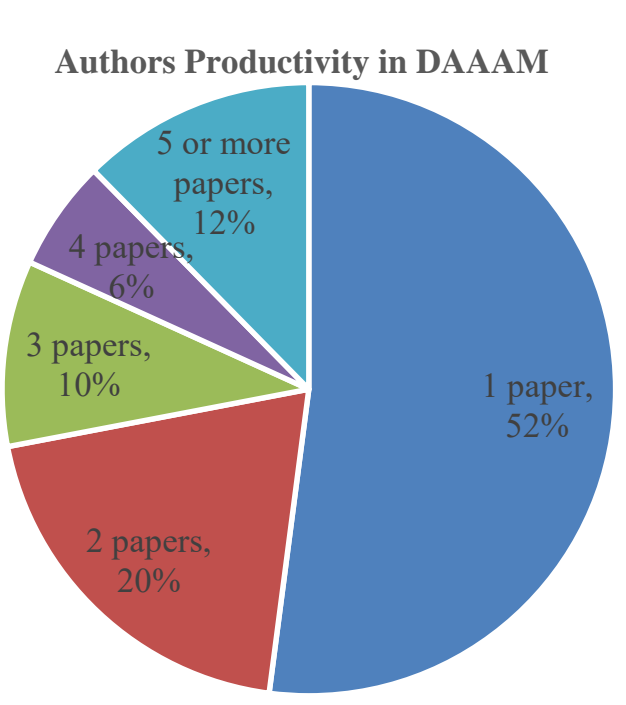

Fig. 4. Frequency of papers per author.

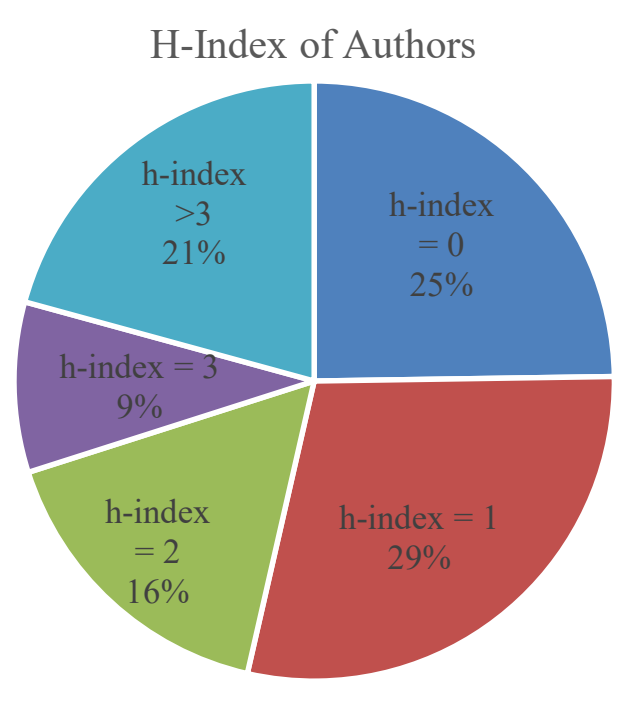

Fig. 5. H-Index of the authors. 
Achsan, H. T.; Suhartanto, H. S. \& Wibowo, W. C.: The Quality and Research Tren...

\begin{tabular}{|r|l|r|r|}
\hline No. & \multicolumn{1}{|c|}{ Subject Area } & $\begin{array}{c}\text { Number } \\
\text { of } \\
\text { Authors }\end{array}$ & Pct. \\
\hline 1 & Engineering & 6,967 & $100 \%$ \\
\hline 2 & Computer Science & 6,190 & $89 \%$ \\
\hline 3 & Materials Science & 2,521 & $36 \%$ \\
\hline 4 & Physics and Astronomy & 1,968 & $28 \%$ \\
\hline 5 & Business & 1,784 & $26 \%$ \\
\hline 6 & Management and Accounting & 1,784 & $26 \%$ \\
\hline 7 & Mathematics & 1,698 & $24 \%$ \\
\hline 8 & Energy & 1,363 & $20 \%$ \\
\hline 9 & Chemistry & 1,131 & $16 \%$ \\
\hline 10 & Environmental Science & 1,108 & $16 \%$ \\
\hline 11 & Social Sciences & 1,047 & $15 \%$ \\
\hline 12 & Chemical Engineering & 991 & $14 \%$ \\
\hline 13 & Decision Sciences & 689 & $10 \%$ \\
\hline 14 & Medicine & 653 & $9 \%$ \\
\hline 15 & Biochemistry & 545 & $8 \%$ \\
\hline 16 & \begin{tabular}{l} 
Genetics and Molecular \\
\hline
\end{tabular} & $8 \% 5$ & $8 \%$. \\
\hline
\end{tabular}

\begin{tabular}{|r|l|r|r|}
\hline No. & \multicolumn{1}{|c|}{ Subject Area } & $\begin{array}{c}\text { Number } \\
\text { of } \\
\text { Authors }\end{array}$ & Pct. \\
\hline 17 & $\begin{array}{l}\text { Earth and Planetary } \\
\text { Sciences }\end{array}$ & 516 & $7.4 \%$ \\
\hline 18 & $\begin{array}{l}\text { Agricultural and } \\
\text { Biological Sciences }\end{array}$ & 511 & $7.3 \%$ \\
\hline 19 & Econometrics and Finance & 347 & $5.0 \%$ \\
\hline 20 & Economics & 347 & $5.0 \%$ \\
\hline 21 & Arts and Humanities & 196 & $2.8 \%$ \\
\hline 22 & Multidisciplinary & 161 & $2.3 \%$ \\
\hline 23 & Health Professions & 134 & $1.9 \%$ \\
\hline 24 & Psychology & 117 & $1.7 \%$ \\
\hline 25 & $\begin{array}{l}\text { Immunology and } \\
\text { Microbiology }\end{array}$ & 92 & $1.3 \%$ \\
\hline 26 & Pharmacology & 88 & $1.3 \%$ \\
\hline 27 & $\begin{array}{l}\text { Toxicology and } \\
\text { Pharmaceutics }\end{array}$ & 88 & $1.3 \%$ \\
\hline 28 & Neuroscience & 86 & $1.2 \%$ \\
\hline 29 & Dentistry & 74 & $1.1 \%$ \\
\hline 30 & Nursing & 39 & $0.6 \%$ \\
\hline 31 & Veterinary & $0.3 \%$ \\
\hline
\end{tabular}

Tab. 2. Subject areas or disciplines of the authors

\begin{tabular}{|r|l|c|c|c|c|c|c|c|c|c|c|c|c|}
\hline No & \multicolumn{1}{|c|}{ Country } & $\mathbf{2 0 0 5}$ & $\mathbf{2 0 0 6}$ & $\mathbf{2 0 0 7}$ & $\mathbf{2 0 0 8}$ & $\mathbf{2 0 0 9}$ & $\mathbf{2 0 1 0}$ & $\mathbf{2 0 1 1}$ & $\mathbf{2 0 1 2}$ & $\mathbf{2 0 1 3}$ & $\mathbf{2 0 1 4}$ & $\mathbf{2 0 1 5}$ & $\mathbf{2 0 1 6}$ \\
\hline 1 & Romania & 29 & 69 & 472 & 1346 & 1644 & 1032 & 577 & 282 & 82 & 65 & 36 & 16 \\
\hline 2 & Czech Republic & 57 & 61 & 69 & 45 & 133 & 271 & 443 & 56 & 80 & 140 & 154 & 63 \\
\hline 3 & Croatia & 98 & 96 & 111 & 139 & 164 & 110 & 171 & 90 & 49 & 56 & 15 & 31 \\
\hline 4 & Slovakia & 24 & 31 & 32 & 142 & 97 & 111 & 254 & 104 & 53 & 31 & 30 & 20 \\
\hline 5 & Estonia & 4 & 58 & 7 & 89 & 23 & 129 & 21 & 202 & 13 & 151 & 61 & 1 \\
\hline 6 & Russian Federation & 7 & 12 & 12 & 16 & 24 & 28 & 47 & 23 & 25 & 106 & 132 & 53 \\
\hline 7 & Bosnia and Herzegovina & 7 & 13 & 26 & 29 & 42 & 23 & 36 & 39 & 37 & 33 & 23 & 44 \\
\hline 8 & Germany & 12 & 28 & 36 & 39 & 62 & 41 & 50 & 14 & 24 & 15 & 7 & 4 \\
\hline 9 & Slovenia & 30 & 42 & 28 & 39 & 34 & 33 & 33 & 15 & 30 & 14 & 6 & 3 \\
\hline 10 & Austria & 16 & 21 & 12 & 7 & 31 & 26 & 31 & 32 & 17 & 42 & 26 & 22 \\
\hline
\end{tabular}

Tab. 3. Authors distribution by country.

\subsection{Publications characteristics}

In this section, we show the differences of our calculation on International Collaboration, Fig. 6, with the International Collaboration diagram displayed on SJR web site, Fig. 1. SJR displayed International Collaboration diagram of "Annals of DAAAM and Proceedings of the International DAAAM Symposium" with a single line laid on zero vertical axis. It means that there was no paper co-authored by researchers from different countries. In contrast, we show that percentage of papers in DAAAM publications on the level $8 \%$ to $16 \%$. 
The difference occurred because SJR uses metadata from Scopus database as it is. Wesearched DAAAM publications from Scopus database using advanced search with query term "conf(DAAAM)" resulting in a list of 5,939 rows of papers metadata. On the left hand side, there were a menu "Country/territory" that showed 4,740 of papers which have no country data. It was also showed that the most papers were authored by researchers from Czech Republic (218 people), followed by Estonia (194 people) and Romania (147 people). If we relied on the search result, only $18.2 \%$ of authors has country data. It was the reason why SJR showed that DAAAM publication has zero percentage in International Collaboration.

Since the papers that has no country data were very significant, so we had to check the authors of all DAAAM publications that were indexed by Scopus one by one. After some treatment as discussed in section 3.2, the authors that has country data raised to $75 \%$, in which, 1,869 authors from Romania, 492 authors from Czech Republic, and 451 authors from Croatia. Using the treated metadata, we can show that percentage of International Collaboration of DAAAM papers in 2016 is $16 \%$. The score is very high, because it is not too far compared to a very prestigious journal "Nature" that has International Collaboration 22\% in 2016.

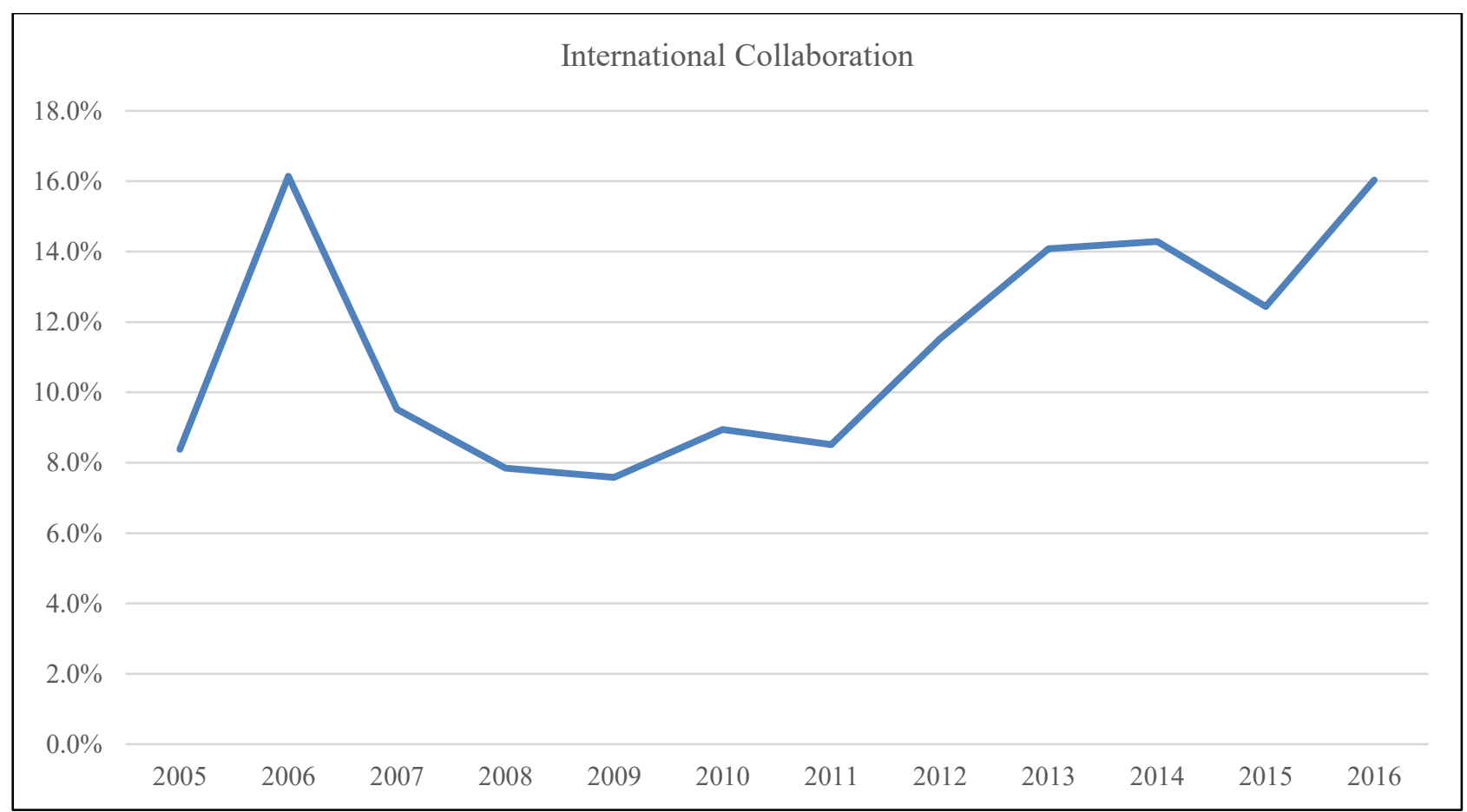

Fig. 6. Percentage of papers coauthored by researchers from different countries.

\subsection{Research trend}

By analysing frequency of authors keywords (Table 4) and two controlled vocabularies on engineering controlled terms and/or Compendex keywords (Table 5) and engineering main headings (Table 6), we can see that the trend of researches published in DAAAM proceedings has shifted from domination of Manufacture in 2011 to very varying research topics in 2016. In our opinion, research trend for the next 3 years are robotic, software/Matlab, automation/control system, and simulation. 
Achsan, H. T.; Suhartanto, H. S. \& Wibowo, W. C.: The Quality and Research Tren...

\begin{tabular}{|c|c|c|c|c|}
\hline $\mathbf{2 0 1 1}$ & $\mathbf{2 0 1 2}$ & $\mathbf{2 0 1 4}$ & $\mathbf{2 0 1 5}$ & $\mathbf{2 0 1 6}$ \\
\hline Manufacture (72) & Manufacture (18) & Cutting tools (9) & Cutting tools (16) & Cutting tools (5) \\
\hline $\begin{array}{c}\text { Computer simulation } \\
(11)\end{array}$ & $\begin{array}{c}\text { Human resource } \\
\text { management (7) }\end{array}$ & Manufacture (8) & 3D printers (8) & Robots (3) \\
\hline Industry (11) & $\begin{array}{c}\text { Computer aided } \\
\text { design (6) }\end{array}$ & $\begin{array}{c}\text { Finite element } \\
\text { method (6) }\end{array}$ & Quality control (8) & $\begin{array}{c}\text { Engineering } \\
\text { education (3) }\end{array}$ \\
\hline Loading (10) & Computer vision (4) & $\begin{array}{c}\text { Uncertainty analysis } \\
(5)\end{array}$ & $\begin{array}{c}\text { Finite element } \\
\text { method (8) }\end{array}$ & $\begin{array}{c}\text { Surface roughness } \\
(3)\end{array}$ \\
\hline Ergonomics (8) & Industry (4) & 3D printers (4) & Robots (7) & Investments (3) \\
\hline
\end{tabular}

Tab. 4. Top five of frequently author keywords.

\begin{tabular}{|c|c|c|c|c|}
\hline 2011 & 2012 & 2014 & 2015 & 2016 \\
\hline $\begin{array}{c}\text { Manufacture } \\
(750)\end{array}$ & $\begin{array}{l}\text { Manufacture } \\
(268)\end{array}$ & $\begin{array}{l}\text { Manufacture } \\
(208)\end{array}$ & $\begin{array}{c}\text { Manufacture } \\
(244)\end{array}$ & $\begin{array}{l}\text { Manufacture } \\
\text { (13) }\end{array}$ \\
\hline $\begin{array}{l}\text { Industry } \\
(44)\end{array}$ & $\begin{array}{l}\text { Manufacturing } \\
\text { process (15) }\end{array}$ & $\begin{array}{c}\text { Automation } \\
\text { (13) }\end{array}$ & $\begin{array}{l}\text { Optimization } \\
\text { (21) }\end{array}$ & $\begin{array}{l}\text { Robots } \\
(10)\end{array}$ \\
\hline $\begin{array}{l}\text { Algorithms } \\
\text { (29) }\end{array}$ & $\begin{array}{l}\text { Design } \\
(15)\end{array}$ & $\begin{array}{l}\text { Cutting } \\
(12)\end{array}$ & $\begin{array}{l}\text { Robots } \\
(19)\end{array}$ & $\begin{array}{c}\text { Automation } \\
(8)\end{array}$ \\
\hline $\begin{array}{l}\text { Optimization } \\
\text { (23) }\end{array}$ & $\begin{array}{l}\text { Industry } \\
(15)\end{array}$ & $\begin{array}{l}\text { Machinery } \\
\text { (12) }\end{array}$ & $\begin{array}{c}\text { Simulation } \\
(18)\end{array}$ & $\begin{array}{c}\text { Computer software } \\
(8)\end{array}$ \\
\hline $\begin{array}{c}\text { Computer simulation } \\
(22)\end{array}$ & $\begin{array}{c}\text { Mechanical properties } \\
\text { (14) }\end{array}$ & $\begin{array}{c}\text { Geometry } \\
(11)\end{array}$ & $\begin{array}{l}\text { Design } \\
(18)\end{array}$ & $\begin{array}{c}\text { MATLAB } \\
(8)\end{array}$ \\
\hline $\begin{array}{c}\text { Mathematical models } \\
(22)\end{array}$ & $\begin{array}{c}\text { Automation } \\
\text { (14) }\end{array}$ & $\begin{array}{c}\text { Computer aided } \\
\text { design (11) }\end{array}$ & $\begin{array}{c}\text { Algorithms } \\
\text { (17) }\end{array}$ & $\begin{array}{c}\text { Control systems } \\
(7)\end{array}$ \\
\hline $\begin{array}{l}\text { Simulation } \\
(20)\end{array}$ & $\begin{array}{l}\text { Machinery } \\
\text { (13) }\end{array}$ & $\begin{array}{c}\text { Milling } \\
\text { (machining) (10) }\end{array}$ & $\begin{array}{l}\text { Cutting tools } \\
\text { (16) }\end{array}$ & $\begin{array}{l}\text { Mobile robots } \\
\text { (7) }\end{array}$ \\
\hline $\begin{array}{c}\text { Competition } \\
(20)\end{array}$ & $\begin{array}{c}\text { Hardness } \\
(12)\end{array}$ & $\begin{array}{c}\text { Computer software } \\
(10)\end{array}$ & $\begin{array}{c}\text { Automation } \\
(16)\end{array}$ & $\begin{array}{l}\text { Cutting } \\
(6)\end{array}$ \\
\hline $\begin{array}{c}\text { Finite element method } \\
(18)\end{array}$ & $\begin{array}{c}\text { Mathematical models } \\
\text { (11) }\end{array}$ & $\begin{array}{l}\text { Decision making } \\
(9)\end{array}$ & $\begin{array}{l}\text { Models } \\
(15)\end{array}$ & $\begin{array}{c}\text { Energy utilization } \\
(5)\end{array}$ \\
\hline $\begin{array}{l}\text { Production engineering } \\
\text { (18) }\end{array}$ & $\begin{array}{l}\text { Research } \\
\text { (11) }\end{array}$ & $\begin{array}{c}\text { Sintering } \\
(9)\end{array}$ & $\begin{array}{l}\text { Machining } \\
\text { (15) }\end{array}$ & $\begin{array}{l}\text { Simulation } \\
(5)\end{array}$ \\
\hline
\end{tabular}

Tab. 5. Top ten of frequently engineering controlled terms and/or Compendex keywords.

\begin{tabular}{|c|c|c|c|c|}
\hline 2011 & 2012 & 2014 & 2015 & 2016 \\
\hline Simulation (20) & Simulation (10) & Simulation (9) & Simulation (25) & Simulation (5) \\
\hline Optimization (18) & Optimization (6) & Software (5) & Optimization (22) & Mobile robot (4) \\
\hline Innovation (10) & Milling (6) & $\begin{array}{l}\text { Mechanical } \\
\text { properties (5) }\end{array}$ & Modelling (14) & Environment (3) \\
\hline $\begin{array}{c}\text { Sustainable } \\
\text { development (10) }\end{array}$ & Hardness (5) & Risk (4) & Roughness (12) & Machining (3) \\
\hline FEM (9) & Analysis (5) & $\begin{array}{l}\text { Image processing } \\
\text { (4) }\end{array}$ & Milling (12) & Matlab (3) \\
\hline
\end{tabular}

Tab. 6. Top five of frequently engineering main headings 


\subsection{Publication quality}

The quality of a serial publication can be measured by its citations as stated before. The graph in Fig. 7 and Fig. 8 shows the number of citation and number of citations per paper yearly. We do not show for the year 2014-2016 because of 2 reasons: paper gets citations after 3 years, and we intended to compare the graph versus the same graph published by SJR. SJR display graph using metadata from 2006-2014, see Fig. 1. However, we know that there is no DAAAM publication indexed by Scopus in 2013, as described in previous section. All DAAAM publications in 2013 were indexed by Scopus in 2014. In other words, our metadata for year 2013 is same as metadata in Scopus for year 2014. Since SJR using metadata from Scopus, then metadata in SJR for year 2014 is same as our metadata for year 2013. So we can compare our graph with SJR graph apple-to-apple.

SJR gives score of Cites per Doc 0.1 for DAAAM publications in 2014, see Fig. 1 upper-left, it is very low compared to our graph below. The difference comes from the number of citations and the number of documents. In the year 2013 in our graph, DAAAM published 206 papers and those papers got 846 citations. In the same year (year 2014 in SJR), SJR showed that DAAAM published 833 documents and those documents got only 83 citations. The number of citations may not be equal because we retrieve the number of citations in 2017 and SJR may retrieve the citations number in 2016. We conclude that the difference is too far since citation count by SJR is only $10 \%$ of our citation count. According to SJR the number of document published by DAAAM is very high, 2,600 documents in 2012 (DAAAM only published 408 documents), 1,628 documents in 2013 (DAAAM only published 206 documents), and 833 documents in 2014(DAAAM only published 287 documents). Those numbers can be searched on SJR web site [3] by hovering the mouse pointer (cursor) on the graph.

The number of documents released by DAAAM is almost equal in number that is indexed by Scopus. The difference is DAAAM do not treat the preface (authored by B. Katalinic) as a scientific paper, but it is treated as a document in Scopus. We do not know how SJR got those large number of DAAAM publications, whereas the source of data is the same, that is Scopus.

As stated by SJR, citations per paper or the quality of DAAAM publications in the year 2014 was only 0.1 ( 83 citations divided by 833 documents). Our research reveals that the citations per paper in the year 2013 was 4.11 , obtained from 846 citations divided by 206 papers. As we used the right metadata, then our citations per paper is the right one. Consequently, DAAAM publications quality is higher than those stated by SJR. 
Achsan, H. T.; Suhartanto, H. S. \& Wibowo, W. C.: The Quality and Research Tren...

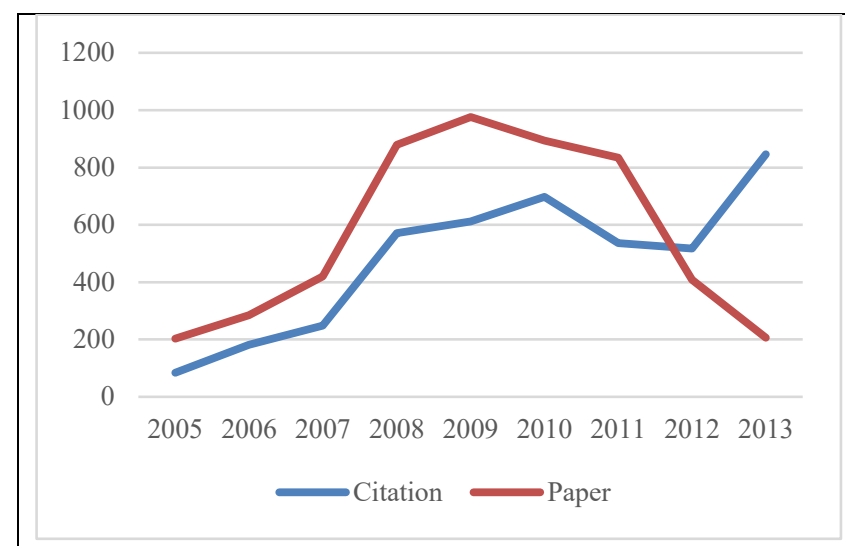

Fig. 7. Number of paper and citations

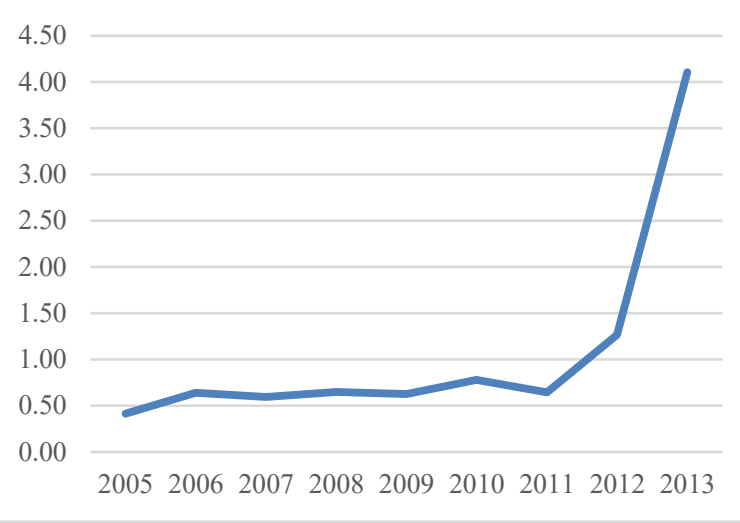

Fig. 8. Number of citations per paper

\section{Conclusion}

Research on publications using bibliometric should use bibliography from many data sources. We could not rely on one data source, metadata from DAAAM web site for example, because DAAAM web site do not publish the citations received by its papers. The number of citations received by each papers published by DAAAM can be retrieved from Scopus. DAAAM also do not have author identifier. It may results in a single author to be treated as some authors. For example, an author named Marko Švaco was published in different names as: Švaco, Marko; Svaco, M.; and Svaco, Marko.

DAAAM publications mostly authored by European researchers (94.1\%), thus the research trend on the subject area Automation and Manufacturing may be generalized to Europe, especially Eastern Europe. The research trend in the next 3 years will be dispersed in many topics, but we predicted that the popular topics will be: robotic, software/Matlab, automation/control system, and simulation. The prediction was based on analysing the last 5 year of authors keywords and controlled/indexed keywords.

It seems that the number of accepted papers in DAAAM conference/symposium is tightened to increase the quality. In 2009 there were 976 papers accepted, but in 2016 only 131 papers were accepted. The most declined was Romanian papers. In 2009 there were 1,644 authors from Romania, nevertheless in 2016 there were only 16 authors from Romania. The quality, expressed by the citations number per document, was increased significantly from year 2011, see Fig. 9.

\section{Acknowledgments}

Part of this research was funded by PITTA Grants (hibah Publikasi Internasional Terindeks untuk Tugas Akhir) fiscal year 2017 from Universitas Indonesia. 


\section{References}

DAAAM International Vienna, "Aim, Scope and Mission," 2510 2017. [Online]. Available: http://daaam.info/?page_id=1605.

Scimago Journal \& Country Rank, "SJR: Scientific Journal Rankings," [Online]. Available: http://www.scimagojr.com/journalrank.php?country=AT. [Accessed 2610 2017].

Scimago Journal \& Country Rank, "Annals of DAAAM and Proceedings of the International DAAAM Symposium," Scimago Journal \& Country Rank, [Online]. Available:

http://www.scimagojr.com/journalsearch.php?q=21100297597\&tip=sid\&clean=0. [Accessed 2510 2017].

J. Machin-Mastromatteo, J. Tarango and E. Medina-Yllescas, "Latin American tripleA journals 1: A quality roadmap from the quality indicators and journals' presence in Web of Science and Scopus," Information Development, vol. 33, no. 4, pp. 436-441, 2017.

K. Sirirak and C. Sirisathitkul, "Walailak Journal of Science and Technology - A scientometric analysis from 2010 to 2015," Walailak Journal of Science and Technology, vol. 13, no. 6, pp. 391-397, 2016.

R. Aleixandre-Benavent, J. González De Dios, L. Castelló Cogollos, C. Navarro Molina, A. Alonso-Arroyo, A. Vidal-Lnfer and R. Lucas-Domínguez, "Bibliometrics and indicators of scientific activity (1). the evaluation of research and scientific activity in pediatrics through bibliometrics," Acta Pediatrica Espanola, vol. 75, no. 1-2, pp. 1825, 2017.

A. Tahim, S. Hilmi and S. Holmes, "How far reaching is our research? An analysis of the journals in which oral and maxillofacial surgery research is cited," British Journal of Oral and Maxillofacial Surgery, vol. 55, no. 5, pp. 538-539, 2017.

$\mathrm{X}$. Gu and K. Blackmore, "Characterisation of academic journals in the digital age," Scientometrics, vol. 100, no. 3, pp. 1333-1350, 2017.

R. Bhardwaj, "Information literacy literature in the social sciences and humanities: a bibliometric study," Information and Learning Science, vol. 118, no. 1-2, pp. 67-89, 2017.

A. Majzoub, K. Al Rumaihi and A. Al Ansari, "The world's contribution to the field of urology in 2015: A bibliometric study," Arab Journal of Urology, vol. 14, no. 4, pp. 241-247, 2016.

B. Jamjoom and A. Jamjoom, "Impact of country-specific characteristics on scientific productivity in clinical neurology research," eNeurologicalSci, vol. 4, pp. 1-3, 2016.

J. S.-M. M. A. S. Jamali, "Factors affecting journal quality indicator in scopus (SCImago Journal Rank) in obstetrics and gynecology journals: A longitudinal study (1999-2013)," Acta Informatica Medica, vol. 22, no. 6, pp. 385-388 , 2014. 
Achsan, H. T.; Suhartanto, H. S. \& Wibowo, W. C.: The Quality and Research Tren...

W. Walters, "Citation-Based Journal Rankings: Key Questions, Metrics, and Data Sources," IEEE Access, 2017.

B. Althouse, J. West, C. Bergstrom and T. Bergstrom, "Differences in impact factor across fields and over time," Journal of the American Society for Information Science and Technology, vol. 60, no. 1, pp. 27-34, 2009.

R. Nivens and S. Otten, "Assessing journal quality in mathematics education," Journal for Research in Mathematics Education, vol. 48, no. 4, pp. 348-368, 2017.

H. T. Y. Achsan and W. C. Wibowo, "A fast distributed focused-web crawling," in 24th DAAAM International Symposium on Intelligent Manufacturing and Automation, Zadar, Croatia, 2014.

H. T. Y. Achsan and Q. K. Barcah, "Indonesia Coal Trade System: A knowledge-based application software,” Energy Procedia, vol. 100, no. C, pp. 622-629, 2015.

H. T. Y. Achsan and Q. Barcah, "Indonesia Coal Trade System: A knowledge-based application software," Procedia Engineering, vol. 100, no. January, pp. 622-629, 2015. G. Pavelin, "Croatian Archives, Libraries and Museums in Online Edition of Daily Newspapers," in DAAAM Scientific Book 2016, Vienna, DAAAM International Vienna, 2016, pp. 407-418.

J. E. Hirsch, "An index to quantify an individual's scientific research output," in Proceedings of the National Academy of Sciences, Stuttgart, Germany, 2005.

J. Hirsch, "Does the h index have predictive power?," in Proceedings of the National Academy of Sciences of the United States of America, 2007.

R. Gray, E. Hassanein and D. Thompson, "Journal editors and their h-index," Journal of Advanced Nursing, vol. 73, no. 9, pp. 2031-2034, 2017.

B. Nie and S. Sun, "Using Text Mining Techniques to Identify Research Trends: A Case Study of Design Research," Applied Sciences, 2017.

R. Vogel, F. Hattke and J. Petersen, "Journal rankings in management and business studies: What rules do we play by?," Research Policy, pp. 1707-1722, 2017.

R. Bhardwaj, "Information literacy literature in the social sciences and humanities: a bibliometric study," Information and Learning Science, vol. 118, no. 1-2, pp. 67-89, 2017. 